症例

\title{
奇静脈瘤の 1 例
}

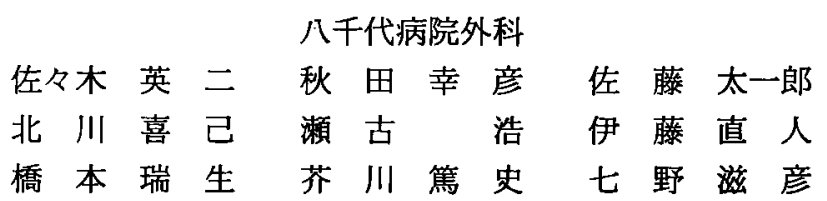

術前に縱隔腫瘍と診断した症例を手術し，奇静脈瘤であったので文献的考察を交え報 告する.

症例は43歳, 女性. 背部痛を主訴として来院, 当初は白血球増多などの炎症所見があっ たが，まもなく消失した．各種画像診断の結果，神経䩬腫がもっとも疑わしい綎隔腫瘍 として手術に望んだ.

開胸すると，軟らかい腫瘤が奇静脈背面にあり，奇静脈との病着が強固なため，合併 切除した。病理組織学的には腫㿔は衰状て，壁は 3 層構造であった。筋層が縦走してお り, 弾性板は認めなかったので, 㹡張した静脈血管と診断された.内腔は血栓が充満し ていた。

術後13力月の現在健康である.

卖引用語：縦隔腫煌, 奇静脈瘤

\section{緒言}

綐隔腫場の診断は各種画像診断法の進歩により，か なり容易になってきた.しかし，綐隔腫煌は種類が多 い上に，非腫湯性でも綻隔の異常陰影を示す病態が数 多くあって, 術前の鑑別診断に困惑する症例も少なく ない，われわれは縦隔腫瘍に酷似した血管性病変「奇 静脈瘤」(aneurysm of the azygos vein) の症例を経 験し, 切除し得たので報告し, 文献的考察を行った.

\section{症例}

症例：43歳，女性，主婦.

主訴：背部痛.

家族歴：特記すべきことはない。

既往歴：帝王切開術 ( 2 回).

現病歴：生来健康で特に異常なかったが，1994年 3 月下旬より，背部痛が続き，軽快しないため，同年 4 月 4 日当院内科に来院した.

初診時現症: 体格良好, 身長平均. 血圧 $140 / 86$, 体 温 $37.3^{\circ} \mathrm{C}$ 。両肩甲骨の間やや右寄りに仰卧位で増悪す る背部痛があったほか, 痰の伴わない咳, 食欲不振, 上腹部不快感を訴えていた。
検査所見：初診時に末梢血の白血球增多が認められ たが, 術前には正常值に回復していた。血液生化学検 査，尿検查では異常は見られなかった（表 1 )。また， 呼吸機能，心電図及び心荿超音波検査には異常所見が みられなかった。胸部 X 線写真の立位正面像（図 1a) では，気管分岐部の高さに右肺に突出する辺緑平滑な 腫瘤影が認められた。また立位側面像（図 1b）では腫 瘤は気管分㞳部後方から圧排していた。食道造影ては， 食道は壁外性に圧排されていた。粘膜面の不整はみら れず，浸潤は考えにくかった(図 2)．同時に行った胸 部透視では腫瘤陰影の大きさに拍動性変化はみられな かった. 造影 CT(図 3)では右後縦隔に腫瘤影を認め, 内部はほほ均一だが，所々軽度造影されている．核磁 気共鳴診断装置 (MRI) T1強調像 (図 4a, b, c, d) では，被膜は high intensity，実質は不均一でやや low intensity を示している. 気管後面の圧排を認めるが, これらの間に存在する脂肪層は連続性を保っており, 浸潤は否定的だった。 MRI-T2強調像（図 4b）は腫瘤 全域にわたり, high intensityであったため, 水分に富 んだ内容が予想された。 また，動脈系との連続を調べ るために，本症例には，シネ MRIが施行された．その 結果, 心動脈系の拍動に腫瘤は連動しておらず, 動脈

1995年 2 月 13 日受付 1995 年 7 月17日採用 
表 1 入院時臨床検査成繦

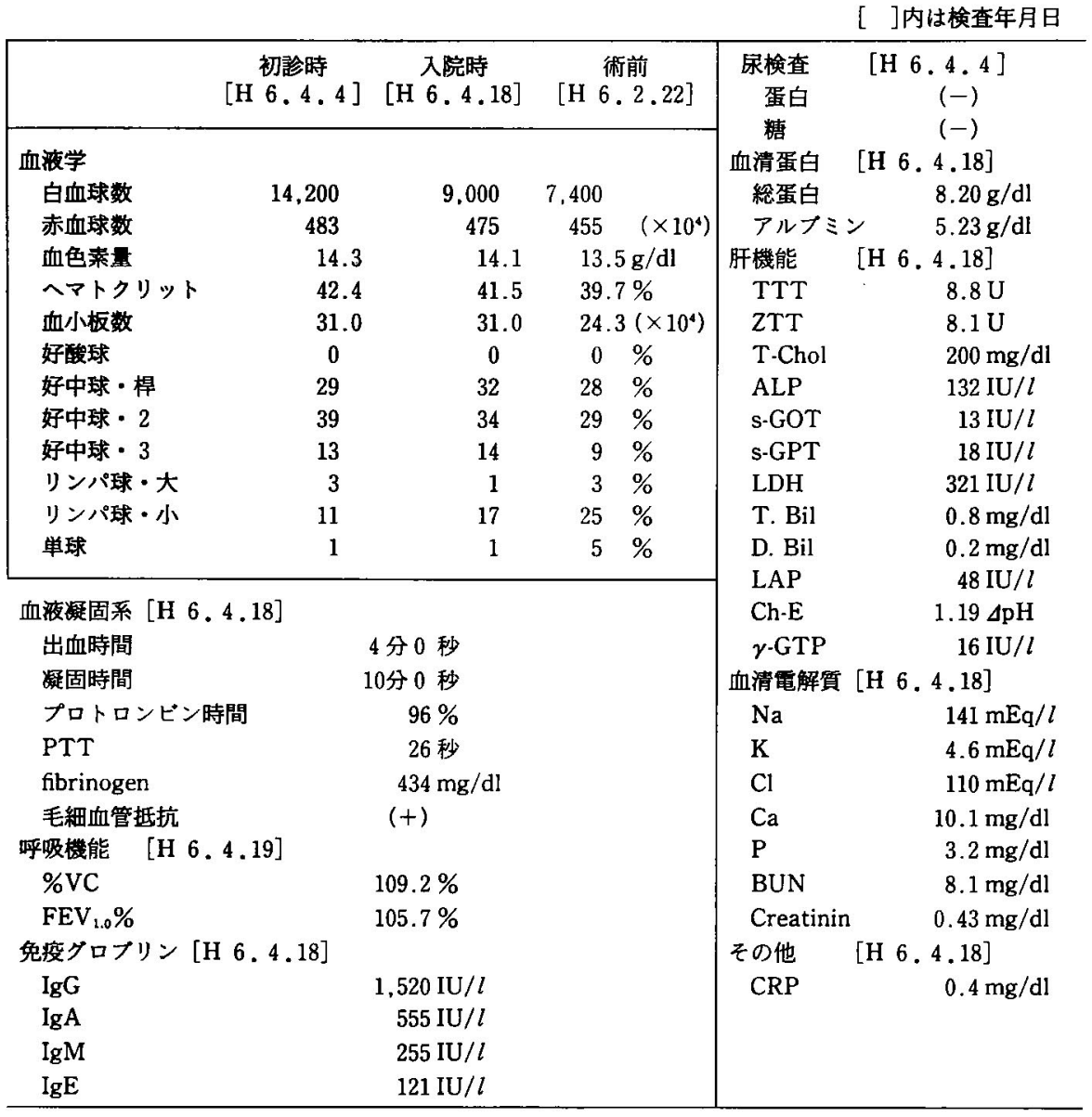

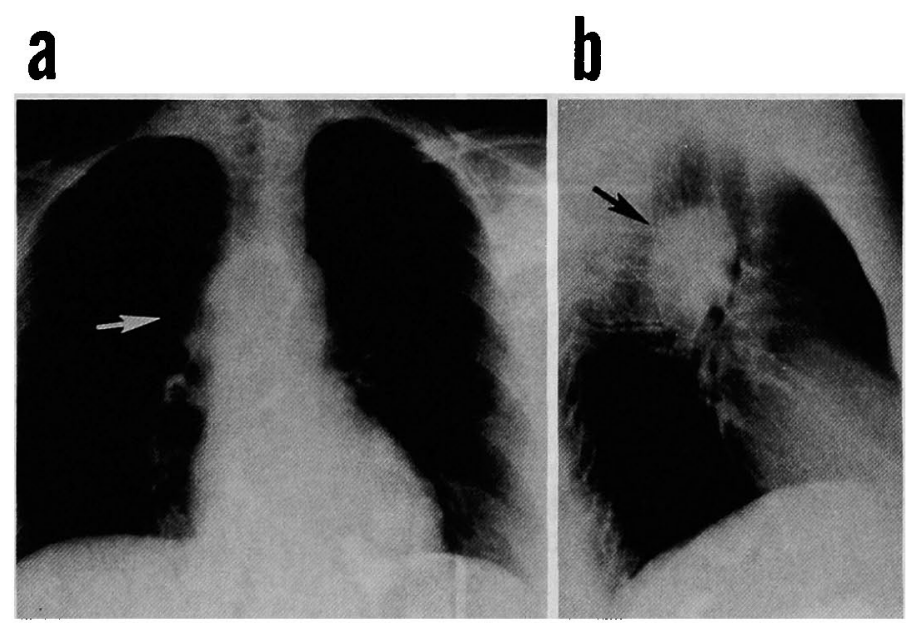

図 1a 胸部 X 線写真立位正面像, b 胸部 X 線写真立位側面像 


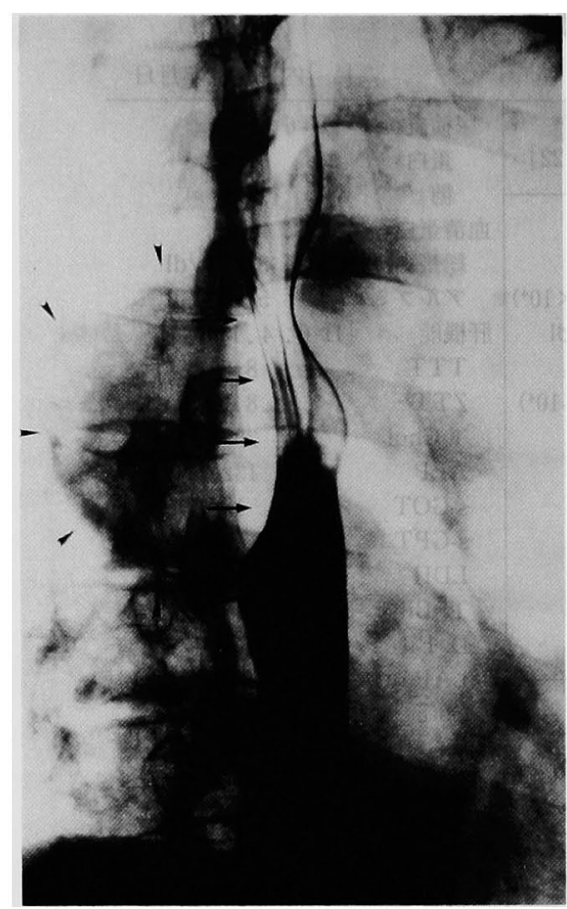

図 2 食道造影

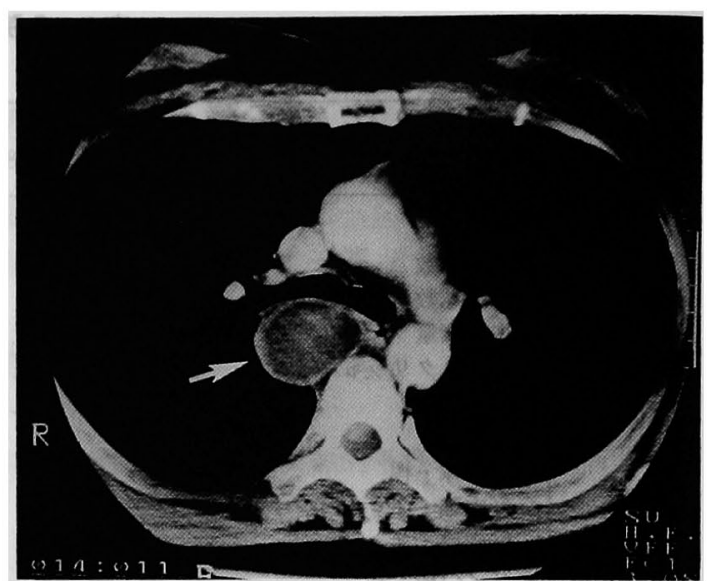

図 3 造影 CT

系との癒着は考えにくかった。

後縦隔原発で, 平滑な被膜を有し, 明らかな浸潤も なく，実質の血流はそしいこと，なおかつ水分に富む 実質であること，また，石灰化や，脂肪の存在は否定 的であることより, 後䅠隔腫瘍, 特に神経鞘腫と診断 した.

手術所見：全身麻酔下左側臥位とし，右後側方切開 第 5 肋間開胸による綐隔腫瘍切除術が施行された（図

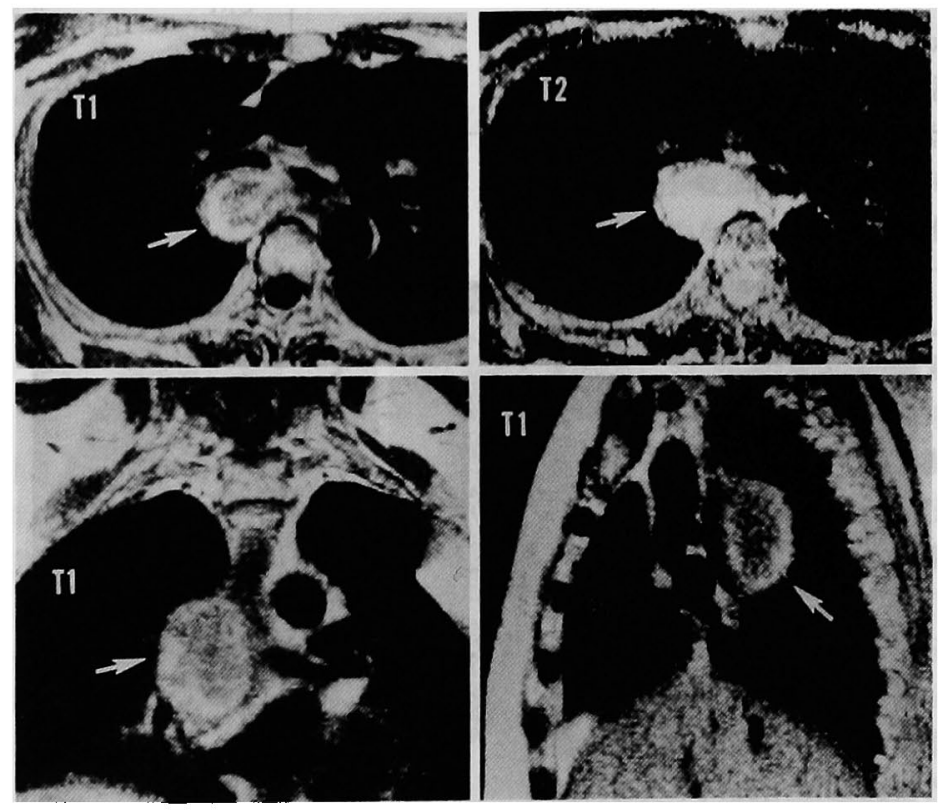

図 4 MRI

\begin{tabular}{l|llll}
$\mathrm{a}$ & $\mathrm{b}$ & $\mathrm{a}$ & $\mathrm{T} 1$ 強調横断像, $\mathrm{b}$ & $\mathrm{T} 2$ 強調横断像 \\
\hline $\mathrm{c}$ & $\mathrm{d}$ & $\mathrm{c}$ & $\mathrm{T} 1$ 強調前額断像, d $\mathrm{T} 1$ 強調矢状断像
\end{tabular} 


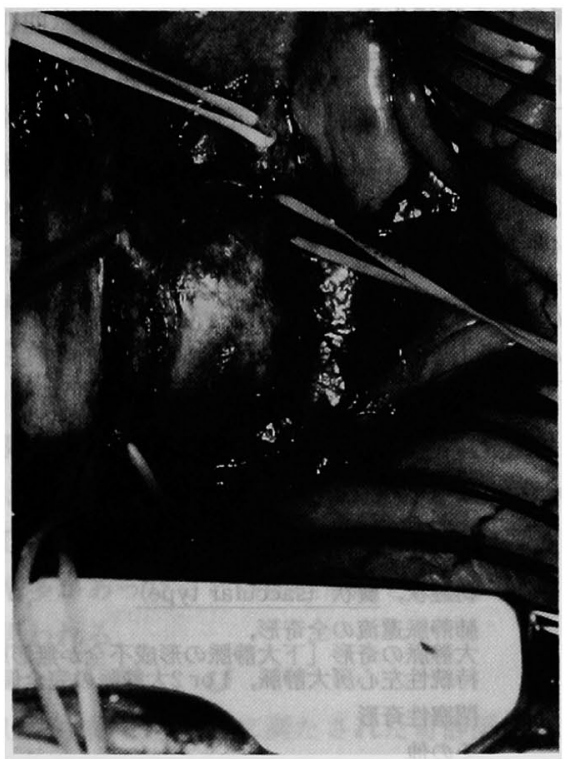

a

図 5a 術中写真, b 衍中写真のシェーマ

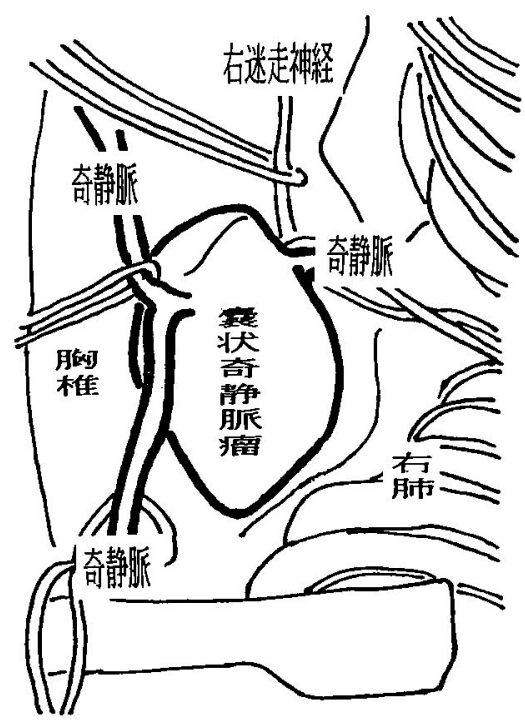

b

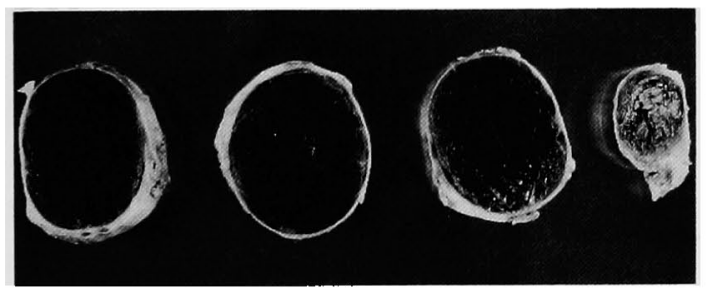

図 6 切除標本断面

5).腫瘍は弾性軟で, 胸椎椎体に接し, 左側では食道, 前方では気管支に瘜着していた，奇静脈水平部自身が 軎状に拡張しており，腫瘤は奇静脈と一塊に摘出され た. 食道・気管支, その他周辺臓器への浸潤は認めら れなかった。

摘出標本：腫瘤は50 $539 \times 30 \mathrm{~mm}$ 大で, 弾性軟，腫 瘤は奇静脈に強固に瘄着していたが，腫瘤へ出入りす る血管は認めなかった，割面では血栓が腫瘤内腔に充 满していた（図6).

病理組織学的検査：腫㢞の壁は 3 層構造であった。 筋層が緥走しており，弾性板は認められなかったので， 拡張した静脈血管と診断された。内腔を埋め尽くして いる血栓に器質化はほとんど認められず，かなり新鮮 な血栓であると診断された，奇静脈との血流連絡路は 組織学的にも認めることができなかった（図 7a, b). 術後経過：術後経過は順調で, 術後第12日目に退院 a

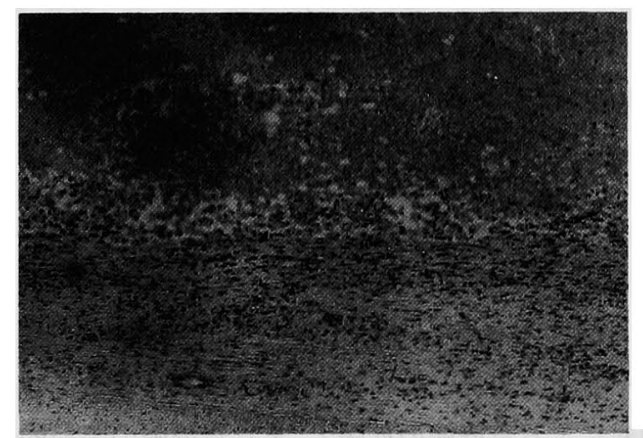

b

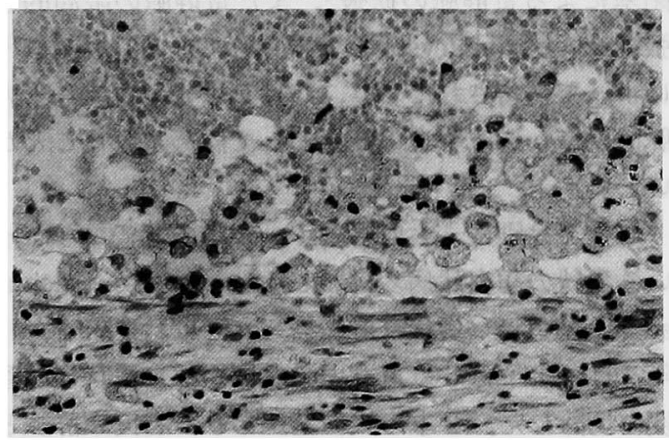

図 7a 病理組織所見 (100倍)，b病理組織所見 $(400$ 倍)

し, 術後13力月の現在，健康で，家事に従事している。 考察

緃隔腫瘍に酷似した静脈性病変では傍食道静脈 
表 2 面状奇静脈㿔の本邦報告例

\begin{tabular}{|c|c|c|c|c|c|}
\hline 報 告 者 & 発表年 & 年龄 & 性 & 大きさ $(\mathrm{mm})$ & 術前診断 \\
\hline Beatty H. Ramsey & 1966 & 69 & 男 & $60 \times 75 \times 80$ & 肺㴦 \\
\hline A. Birecka-Jaworska & 1973 & 45 & 男 & $50 \times 50 \times 50$ & 縦隔腫瘍 \\
\hline 高橋 洋 & 1984 & 39 & 女 & $55 \times 60 \times 50$ & 咅胞性腫瘍 \\
\hline 池田修平 & 1985 & 46 & 女 & - & 縱隔腫霚 \\
\hline L. Seebauer & 1988 & 54 & 女 & $150 \times 70$ & 上大静脈瘤 \\
\hline Y. Kurihara & 1993 & 62 & 男 & - & 縦隔腫孺 \\
\hline 自跧例 & 1994 & 43 & 女 & $50 \times 39 \times 30$ & 綖隔腫疸 \\
\hline
\end{tabular}

表 3 大静脈系の Aneurysmal な病变の分類

\begin{tabular}{|c|c|}
\hline $\begin{array}{l}\text { I. Congenital lesions } \\
\text { I. A. Primary or Simple } \\
\text { I. B. Secondary or Complex }\end{array}$ & $\begin{array}{l}\text { I. 先天性病変 } \\
\text { 紡錘状, 重状 (saccular type) } \\
\text { 肺静脈還流の全奇形, } \\
\text { 大静脈の奇の形成不全か無形成, } \\
\text { 持続性左心房大静脈, } 1 \text { or } 2 \text { 静脈の完全偏位] }\end{array}$ \\
\hline $\begin{array}{l}\text { I. C. Obstructive anomalies } \\
\text { I. D. Miscellaneous }\end{array}$ & $\begin{array}{l}\text { 閉塞性奇形 } \\
\text { その他 }\end{array}$ \\
\hline $\begin{array}{l}\text { II. Acquired lesions } \\
\text { II. A. Primary } \\
\text { II. B. Secondary }\end{array}$ & $\begin{array}{l}\text { II. 後天性病変 } \\
\text { 紡鍾形 } \\
\text { 外傷, 閉塞：静脈瘠, 近接した新生物 }\end{array}$ \\
\hline $\begin{array}{l}\text { III. Pseudo-aneurysms } \\
\text { III. A. Transient }\end{array}$ & $\begin{array}{l}\text { III. 仮性動脈瘤 } \\
\text { 一過性病変 [心不全, 心不全と Budd-Chiari 症 } \\
\text { 候群] }\end{array}$ \\
\hline III. B. Venous neoplasms & 静脈の新生物 \\
\hline $\begin{array}{l}\text { IV. Arteriovenous aneurysms } \\
\text { IV. A. Congenital } \\
\text { IV. B. Acquired }\end{array}$ & $\begin{array}{l}\text { IV. 動静脈溜 } \\
\text { 先天性[体循環系, 体循環と肺循謤系, 類静眽 }] \\
\text { 後天性 }[\text { 梅毒] }\end{array}$ \\
\hline
\end{tabular}

Abbott (1964) による

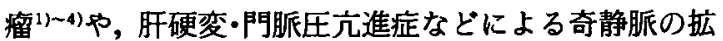

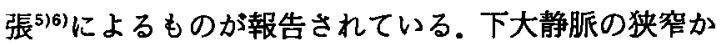
閉塞による奇静脈の拡張》，また奇静脈の限局的な拡 張 (azygos aneurysm と表現されている) が諸家 ${ }^{8)-12)}$ によって報告されており，しばしば先天性で,下大静 脈の狭窄か形成不全の結果として諗められることが多 いという.

以上とは別に，大血管と $1 ， 2$ 本の荎でつながって

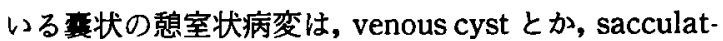
ed aneurysm（震状奇静脈瘤）と呼ばれている. 1928 年, Harris ${ }^{13)}$ は 5 力女児の右側頸部に倠状の血管病 変を切除した。 2 本の太い荎があり, 右内頸静脈と右 無名静脈に連絡していたといい, conjenital venous cyst と名付けた. 1966年, Ramsay ${ }^{14)}$ $^{5}$, sacculated aneurysm of the azygos vein として, その第 1 例を

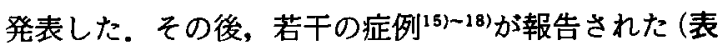
2 ).

ここで用語について説明する必要がある。1964年
Abbott $^{19)}$ 上大静脈系の aneurysmal な拡張について 整理し，体系化した記述を残した(表 3)．食道静脈瘤 は食道粘膜下，傍食道静脈瘤は食道外膜下を意味して いる3．1970年 Bell は「従来, aneurysm という名称は 動脈のみに適応されていたが, 静脈の㹡張が長径にお いて異常がなければ varixよりも venous aneurysm のほうが適切であろう」と述べている20).

糞状奇静脈瘤はこれまでに6 例報告されてい

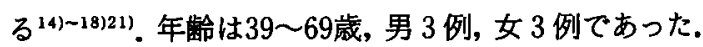
大きさは 5 $10 \mathrm{~cm}$ 程度であり，前例とも切除された。 しかし，術前に正確に診断された症例はなかった。腫 瘤と奇静脈は多くは $1 \mathrm{~cm}$ 程度の茎で連絡されている が,拍動はみられていない.ただ,例外的に Seebauer ${ }^{17)}$ の症例のみが拍動ありとされている. Ramsey ${ }^{14)}$ 症 例で手術中に圧迫したら縮小したと言うが，他の症 例と同じく拍動を認めていない。

Seebauer ${ }^{17) の}$ 症例は拍動性があるため，CT, MRI のほか縦隔静脈造影によりかなり正確な診断に近づい 
たが，腫瘤との血流路が同定できなかったため術前診 断では衰状上大静脈瘤と考えた。

一方，自験例ては奇静脈水平部が確認できなかった が，奇静脈の垂直部に㹡張などの異常を認めなかった ことから血栓の充満していた静脈瘤とは別経路に奇静 脈水平部は開存していたと考えられる。また，病理組 織学的に静脈瘤の壁には腫瘍性の变化を認めておら ず，奇静脈壁自体から発生した襄状血管腫も否定され た、以上から自験例は裹状奇静脈瘤が最も考えられた。 なお，自験例で静脈瘤内が比較的新しい血栓で满た されていたのは, 最近, なんらかの炎症が起こって血 栓形成を誘発したと思われる.初診時に背部痛を訴え， 発熱や白血球増多があったことは血栓形成と因果関係 があるように思われる。

\section{結び}

綎隔腫瘍として手術し，血栓に満たされた奇静脈瘤 を切除した症例を報告し，文献的考察を加えた。

脱稿するに当たり，病理組織診断にご指導を賜った藤田 保健衛生大学医学部病態細胞教室の社本幹博教授に謝意を 表する.

\section{文献}

1）高安賢一, 志真泰夫, 小林千鶴子他：綐隔腫場と誤 認された巨大な傍食道静脈瘤の 1 例。日消外会誌 $78: 2412-2416,1981$

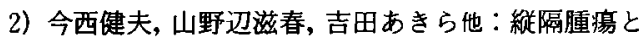
誤認された傍食道静脈瘤の 1 例. 臨と研 $62: 888$ $-889,1985$

3）新野順，林 邦昭，上谷邦孝他：胸部 $\mathrm{X}$ 線写真 で認められた偽腫瘍性静脈㾇。臨放線 $31: 871-$ 876,1986

4）岡田 実, 蜂屋順一：単純 $X$ 線写真加ら始まる画 像診断 (8) 傍食道静脈瘤. 日医新報 $3421: 79-82$, 1989

5) Compbell HE, Baruch RJ : Aneurysm of hemiazygos vein associated with portal hypertension. Am J Roentgen 83 : 1024-1026, 1960

6）橋本 学,玉川芳春, 阿部啓二：綻隔腫被陰影々門 脈の石灰化を認めた肝硬変の 1 例。秋田医誌会誌 $37: 168-171,1985$

7) Castellino RA, Blank N, Adams DF, et al: Dilated azygos and hemiazygos veins present. ing as paravertebral intrathoracic masses. $\mathrm{N}$
Engl J Med 278 : 1087-1091, 1968

8) Shuford WH, HS WEENS: Azygos vein dilatation simulating mediastinal tumor. Am J Roentgen $80: 225-230,1958$

9) Bogedain W, John Carpathios: Dilated azygos vein simulating mediastinal tumor. Postgraduate Medicine 31 : 490-000, 1962

10) Walker WA: Aneurysm of the Azygos vein, etiology undetermined. Am J Roentgen $90: 575$ $-577,1963$

11) Olbert F, Kobinia G, Neumann I: Angiographic demonstration of azygos aneurysm. Ann Radiol (Paris) 23 : 363-368, 1980

12) Lahiri TK, Vaswani DK, Srivastava BK, et al : Aneurysmal dilatation of azygos vein. Indioan $\mathrm{J}$ Chest Dis Allied SCI 25: 290-293, 1983

13) Haris RI: Congenital venous cyst of the mediastinum. Ann Surg 88: 953-957, 1928

14) Ramsey BH: A sacculated aneurysm of the azygos vein. Ann Thorac Surg 2:213-216, 1966

15）高橋 洋, 中村順児, 小山隆司他：奇静脈瘤の 1 治 験例. 胸部外科 $37: 568-601,1984$

16）池田修平，国島和夫，陶山元一他：奇静脈瘤の 1 例．日胸疾患会誌 $23: 1385,1985$

17) Seebauer L, Prauer HW, Gmeinwieser J, et al : A mediastinal tumor simulated by a sacculated aneurysm of the azygos vein. Thorac Cardiovasc Surg 37: 112-114, 1989

18) Kurihara $Y$, Nakajima $Y$, Ishikawa $T$ : Case report: Saccular aneurysm of the azygos vein simulating a paratracheal tumor. Clin Radiol 48: 427-428, 1993

19) Abbott OA, Ted F Leigh : Aneurysmal dilata tion of the superior vena caval system. Ann Surg $159: 858-872,1964$

20）川井田孝, 入来敦久, 田中俊正他：上大静脈におけ る巨大な idiopathic aneurysmal dilatation $の 1$ 手術例。日胸外会誌 $25 ： 1074-1079,1977$

21) Birecka-Jaworska A, Wozniewicz B : Przypadek zylaka zyly nieparzystej rozpoznawany jako guz srodpiersia. Polski preglad Chirurgiczny $45: 1445,1973$ 


\section{AN ANEURYSM OF THE AZYGOS VEIN}

Eiji SASAKI, Yukihiko AKITA, Taichirou SATO, Yoshimi KITAGAWA, Hiroshi SEKO, Naoto ITO, Mizuo HASHIMOTO, Atsushi AKUTAGAWA and Shigehiko SHICHINO

Department of Surgical, Yachiyo Hospital

The following is a case report of a large aneurysm probably arising from the azygos vein. A 43-year-old woman was admitted to the hospital because of dorsalgia.

After examinations including plain film of X-ray, ultrasonography, computed sonography, and magnetic resonance imaging, thoracotomy was performed under a diagnosis of suspected neurinoma in the posterior mediastinal space. There was a cystic tumor behind the azygos vein, that was $50 \times 39 \times$ $30 \mathrm{~mm}$ in size without pulsation and the content was conjectured fresh clot. The cyst with the azygos vein was excised because of severe adhesion between them. Postoperative course was uneventfull. Microscopically the wall of the aneurysmal portion showed three layers of the venous structure.

Postoperative course is uneventfull. 